\title{
BLOOD-SUCKING LICE MAY DISSEMINATE Trypanosoma cruzi INFECTION IN BABOONS
}

\author{
Enrique R. ARGAÑARAZ(1), Gene B. HUBBARD(2), Larissa A. RAMOS(1), Allen L. FORD(3), Nadjar NITZ(1), Michelle M. LELAND(4), John L. VANDEBERG(3) \&
} Antonio R.L. TEIXEIRA(1)

\begin{abstract}
SUMMARY
Trypanosoma cruzi (Schyzotrypanum, Chagas, 1909), and Chagas disease are endemic in captive-reared baboons at the Southwest Foundation for Biomedical Research, San Antonio, Texas. We obtained PCR amplification products from DNA extracted from sucking lice collected from the hair and skin of T. cruzi-infected baboons, with specific nested sets of primers for the protozoan kinetoplast DNA, and nuclear DNA. These products were hybridized to their complementary internal sequences. Selected sequences were cloned and sequencing established the presence of $T$. cruzi nuclear DNA, and minicircle kDNA. Competitive PCR with a kDNA set of primers determined the quantity of approximately $23.9 \pm 18.2 \mathrm{~T}$. cruzi per louse. This finding suggests that the louse may be a vector incidentally contributing to the dissemination of $T$. cruzi infection in the baboon colony.
\end{abstract}

KEYWORDS: Baboons; Papio hamadrias; Lice; Pedicinus obtusus; Trypanosoma cruzi infection.

\section{INTRODUCTION}

American trypanosomiasis is a zoonanthroponosis caused by the kinetoplastid protozoan Trypanosoma cruzi. The infection leads to Chagas disease, a chronic consumptive ailment affecting the heart and the digestive tube of susceptible hosts ${ }^{25}$. Wild mammals dwelling on the American continents serve as $T$. cruzi reservoirs that maintain the parasite in nature ${ }^{12}$. The geographic distribution of $T$. cruzi infection coincides with that of its vector, blood-feeding reduviid bugs of the subfamily Triatominae that are found in tropical and subtropical regions, within latitudes $42{ }^{\circ} \mathrm{N}$ to $43^{\circ} \mathrm{S}$. When the protozoan infection gets established in the reduviid host it persists for the entire 1-year life of the host. The triatomids are nocturnal, hiding in the daytime and emerging at night when they attack the sleeping prey. The sylvatic species may fly from their diurnal hiding places to feed on a host located some distance away ${ }^{22}$. Contamination of a host with metacyclic forms of the parasite in the feces of the reduviids has been associated with the human disease ${ }^{25}$. Serological evidences have shown the prevalence of $T$. cruzi infections ranges from 0.43 per cent in Georgia, $\mathrm{USA}^{7}$, to 74.2 per cent in rural areas of Santiago del Estero, Argentina ${ }^{6}$. It has been estimated that 18 million people are chronically infected with $T$. cruzi, and 35 million are at risk of contracting the infection ${ }^{31}$.

Transplacental transmission of T. cruzi may occur in $2.5 \%$ of human fetuses of infected mothers ${ }^{2,3,9,20}$. Breast-feeding has been associated with transmission of $T$. cruzi from infected mothers to their infants, but further studies are needed to determine the epidemiologic importance of this route of transmission ${ }^{15}$. T. cruzi has been considered the most infective blood protozoan, and several cases of accidental transmission to laboratory workers have been reported ${ }^{4}$. In addition, oral transmission of T. cruzi is well documented, and is often related to consumption of insectivorous and carnivorous mammals ${ }^{25}$.

The Anoplura (or sucking lice) live on the surface of the host. To our knowledge, the possibility that sucking lice of the family Pediculidae Linaeus, 1758, comprising the genera Pedicinus, Pediculus and Phthirus, are capable of transmiting of $T$. cruzi has not previously been investigated. We have tested this hypothesis in a baboon (Papio hamadryas, Cercopithecidae) colony ${ }^{16}$, which is maintained in large open-air pens in San Antonio, Texas ${ }^{19}$. In this colony, serological data indicate T. cruzi infection in $9.4 \%$ of 2-to-3-year-olds, $14.0 \%$ of 7-to-10-year-olds, and $22.5 \%$ of baboons that are 15 years old or older (unpublished data). In this study we show that sucking lice, Pedicinus obtusus, captured from nine baboons reared in the colony, yielded PCR amplification products of $T$. cruzi kinetoplast (kDNA) and nuclear (nDNA) DNA with specific primers. Cloning and sequencing the PCR products confirmed the presence of the parasite DNA in the lice.

\section{MATERIALS AND METHODS}

Baboons: This investigation was conducted with animals from a breeding colony of approximately 3,300 baboons, whose members have been useful animal models in many areas of biomedical research ${ }^{29,30}$. An earlier observation of natural death of an infant baboon ${ }^{8}$ infected with $T$. cruzi and a more recent observation of three baboons that died spontaneously and exhibited nests of amastigote forms of T. cruzi in

(1) Chagas Disease Multidisciplinary Research Laboratory, Faculty of Medicine, University of Brasília, Federal District, Brazil.

(2) Department of Laboratory Animal Medicine, Southwest Foundation for Biomedical Research, San Antonio, Texas.

(3) Department of Physiology and Medicine, Southwest Foundation for Biomedical Research, San Antonio, Texas.

(4) Department of Genetics, Southwest Regional Primate Research Center, Southwest Foundation for Biomedical Research, San Antonio, Texas.

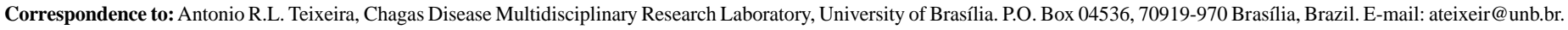
Fax: 55+61 273-4645. Tel.: 55+61 349-4987. 


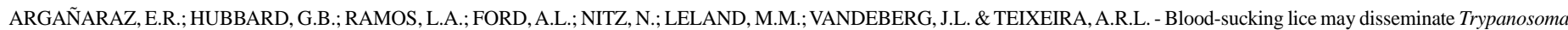
cruzi infection in baboons. Rev. Inst. Med. trop. S. Paulo, 43(5):271-276, 2001.

host cells and lesions consistent with Chagas heart disease (unpublished data) prompted us to search T. cruzi infection in a cohort of 30 baboons. The enzyme-linked immunosorbent assay, indirect hemagglutination, and indirect immunofluorescence assays ${ }^{28}$ were used to determine the presence of specific antibodies in the serum. These positive assays are regarded as evidence of $T$. cruzi infection ${ }^{31}$. In adition, $2 \mathrm{~mL}$ blood samples drawn from six baboons were seeded in $10 \mathrm{~mL}$ of liver infusion tryptose medium. Aliquots of each culture tube were examined monthly for eight months.

Collection of lice and extraction of DNA: We collected P. obtusus (Fig. 1) from the hair and skin of severely parasitized baboons in the colony. Bulk samples of lice from each baboon was pooled, fixed in $70 \%$ ethanol and subjected to DNA extraction ${ }^{1,21}$. DNA was extracted from the blood, and from the heart of baboons that died of Chagas disease. DNA was also extracted from epimastigote forms of Berenice T. cruzi grown in axenic medium ${ }^{27}$ and from macrophage line P388DI-IL1 grown in Dulbecco's Minimum Essential Medium supplemented with $20 \%$ fetal calf serum, $100 \mu \mathrm{g} / \mathrm{mL}$ streptomycin and $100 \mathrm{IU}$ penicillin ${ }^{26}$.

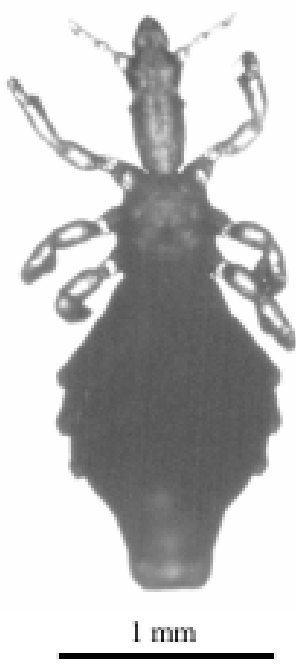

Fig. 1 - Adult Pedicinus obtusus, the Anoplura sucking lice.

Polymerase chain reaction (PCR): DNA was analyzed by PCR with specific primers for the constant minicircle $\mathrm{kDNA}$ region ${ }^{1,21,23}$, and for highly repetitive sequence ${ }^{18}$ of nDNA of $T$. cruzi. The kDNA primer set (S35, 5'-ATAATGTACGGG(T/G)GAGATGC-3' and S36, 5'GGTTCGATTGGGGTTGGTG-3') annealing to the constant region of minicircles yields a $330 \mathrm{bp}$ product and its catamer of $660 \mathrm{bp}^{23}$. The nDNA primer set (PON1, 5'-TGGCTTGGAGGAGTTATTGT-3' and PON2, 5'-AGGAGTGACGGTTGATCAGT-3') amplifies a $250 \mathrm{bp}$ fragment ${ }^{18}$. A DNA thermal cycler (MJ Research, Watertown, MA) was used for 30-32 cycles as follows: PON1/2, $94{ }^{\circ} \mathrm{C}$ for $2 \mathrm{~min}, 58{ }^{\circ} \mathrm{C}$ for $1 \mathrm{~min}$, and $72{ }^{\circ} \mathrm{C}$ for $1 \mathrm{~min}$; S35/36, $94{ }^{\circ} \mathrm{C}$ for $2 \mathrm{~min}, 64{ }^{\circ} \mathrm{C}$ for $1 \mathrm{~min}$, and $72{ }^{\circ} \mathrm{C}$ for $1 \mathrm{~min}$. The reactions were run with $100 \mathrm{ng}$ of lice target template and with $50 \mathrm{pg}$ of DNA from $T$. cruzi culture forms. Each reaction was done in $25 \mu \mathrm{L}$ aliquots containing $2.5 \mathrm{U}$ of Taq polymerase (Perkin Elmer, Cetus Norwalk), $0.2 \mathrm{mM}$ dNTPs, $50 \mathrm{mM}$ Tris- $\mathrm{HCl}$ (pH 9.0 at $20{ }^{\circ} \mathrm{C}$ ), $1.5 \mathrm{mM} \mathrm{MgCl} 200 \mathrm{mM}$ ammonium sulfate, and $5 \mu \mathrm{M}$ each primer. A $10 \mu \mathrm{L}$ aliquot from each PCR reaction was subjected to a $1 \%$ agarose gel eletrophoresis. Negative controls (water, healthy baboon DNA, and P388D1-IL1 DNA) and positive control (T. cruzi DNA) were always included to detect DNA contamination and ensure that the PCR worked efficiently.

Competition assays: After the presence of T. cruzi in sucking lice was confirmed in nine bulk samples, we ran competitive PCR assays with $S 35 / 36$ primers set to quantify the number of parasites in these samples ${ }^{5}$. These assays consisted of a mixture of an unknown quantity of $T$. cruzi template minicircle DNA with serial dilutions of a known quantity of competitor DNA (pT7 Blue vector containing the $280 \mathrm{pb}$ kDNA fragment). The competitor fragment binds the same primers and yields a product that is distinguishable from the sample template (280 versus. $330 \mathrm{bp}$ ). The equivalency point corresponds to the tube with equimolar concentrations of template and competitor PCR products in the reaction mix. The determination of equivalency points was made by visual comparison in $1.5 \%$ wide range agarose $/ 0.5 \%$ standard agarose gel. In all PCR positive samples, using the known amount of the competitor DNA in the reaction, the unknown quantity of the template was calculated, under the asssumption that there were 10,000 minicircles/ parasite and, thus $15 \mathrm{fg}$ of $330 \mathrm{bp}$ template/parasite ${ }^{5}$.

Hybridization, cloning and sequencing: The PCR amplification products were transferred by capillarity to a nylon membrane. Prehybridization and hybridization were performed in 6X SSC, 5X Denhardt's, $0.5 \%$ SDS and $100 \mu \mathrm{g} / \mathrm{mL}$ salmon DNA solution. The membranes were prehybridized for $4 \mathrm{hr}$, and then were hybridized for $12 \mathrm{hr}$ with internal oligonucleotide sequences for different amplified fragments. For S35/36 products ${ }^{23}$, the sequence was S67 5'GGTTTTGGGAGGGG(CG)-(G/C)-(T/G)TC-3'. For PON1/2 products $^{18}$, the sequence was PON3 5'-CCGGCCTGTGTCTGCGGC-3'. These oligonucleotides were radiolabelled with $\left[\gamma^{32} \mathrm{P}\right]-\mathrm{dATP}(3000 \mathrm{CimMol})$ using the polynucleotide kinase method following the manufacturer's recomendation (Life Technologies). After the membrane was washed once for $5 \mathrm{~min}$ with $1 \mathrm{X} \mathrm{SSC}$ and $0.1 \%$ SDS and twice for $30 \mathrm{~min}$ each with $0.2 \mathrm{XSSC}$ and $0.1 \% \mathrm{SDS}$, it was autoradiographed for variable periods of time.

The amplification products obtained with specific kDNA primers were cloned into PCRII vector, and several clones were selected and subjected to sequencing using an $f$-mol DNA cycle sequencing system (Promega). The sequences were submitted to PDU, GBU, GenBank and EMBL BLAST analyses.

\section{RESULTS}

Phenotypic and genotypic markers of Trypanosoma cruzi infection: Phenotypic and genotypic markers that indicate the presence of $T$. cruzi infection in the baboon colony reared in outdoor cages at the Southwest Foundation for Biomedical Research, San Antonio, Texas, are shown in Table 1. The results of three serologic assays covalidated the PCR amplification products from target template $T$. cruzi DNA extracted from blood or tissue samples of 30 baboons. Furthermore, the culture of blood from three out of six baboons yielded parasitic forms of T. cruzi that were inoculated in BALB/c mice. Culture of macerated louse tissue was not performed because samples were received in $70 \%$ ethanol. The animals showed trypomastigote forms in the blood and amastigote forms of $T$. cruzi encysted in tissue cells (data not shown). 
Then, we collected lice from the skin of those three baboons that showed parasitemia and from six others showing positive serologic tests and clinical evidence of the infection.

Detection of Trypanosoma cruzi from Pedicinus obtusus: Here we tested the hypothesis that the blood sucking lice $P$. obtusus may play some role in disseminating the $T$. cruzi among members of the baboon colony. In the absence of direct demonstration of live T. cruzi in lice, the evidence supporting this hypothesis is derived from PCR amplification of sequences from lice target template DNA with specific nested sets of T. cruzi $\mathrm{kDNA}^{23}$, and $\mathrm{nDNA}^{18}$ primers. Table 2 summarizes results of experiments showing that lice captured from the hair, and from the skin of baboons with Chagas disease are infected with the T. cruzi. This evidence was given by PCR with nested sets of primers annealing to the protozoan kDNA, and nDNA templates. In the control experiment, 20 lice collected from the hair, and from the skin from a healthy baboon

Table 1

Phenotypic and genotypic markers of Trypanosoma cruzi identified in baboon tissue

\begin{tabular}{cccccc}
\hline & & \multicolumn{2}{c}{ Phenotype* $^{\text {No. of }}$} & & \multicolumn{2}{c}{ PCR Genotype $^{\mathrm{T}}$} \\
\cline { 5 - 6 } baboons & $\begin{array}{c}\text { No. of baboons } \\
\text { with specific } \\
\text { antibodies }\end{array}$ & & $\begin{array}{c}\text { No. of baboons } \\
\text { with kDNA }\end{array}$ & $\begin{array}{c}\text { No. of baboons } \\
\text { with nDNA }\end{array}$ \\
\hline Positive & 20 & 20 & 17 & 17 \\
Negative & 10 & 0 & 1 & 0 \\
\hline
\end{tabular}

* Enzyme-linked immunosorbent assay, indirect hemagglutination, and indirect immunofluorescence assays identified specific antibodies against $T$. cruzi antigens. The presence of at least two positive assays for each of 20 baboon samples is regarded as an evidence of infection; " $\mathrm{PCR}$ amplification products from target template DNA extracted from blood or tissue samples of 30 baboons, using specific sets of kDNA and nDNA primers. reared in a cage far apart from that having $T$. cruzi infected baboons, and that yielded negative PCR for the protozoan infection.

Figure 2A shows PCR amplification products with specific kDNA primers. The amplification products hybridized with an internal kDNA probe (Fig. 2B). Sequencing of the PCR amplification product showed typical constant and hypervariable kDNA minicircle regions. This sequence is deposited in GenBank (accession number AF114153). Confirmation of the presence of $T$. cruzi DNA in the target template extracted from bulk samples of lice (Table 2) was obtained by PCR with a PON1/2 nested set of primers (Fig. 3A). The amplification product of 250 bp hybridized with its complementary internal sequence, thus showing its specificity (Fig. 3B). This amplification of the parasite nDNA suggested the presence of living $T$. cruzi in the sucking louse.

Quantitation of living Trypanosoma cruzi in lice: Therefore, we performed competitive, quantitative PCR with a kDNA-nested set of primers to determine the number of parasites in each louse ${ }^{5}$. To determine the sensitivity of this quantitative procedure we used concentrations of T. cruzi DNA corresponding to 1, 10 and 100 parasites. Figure 4A shows

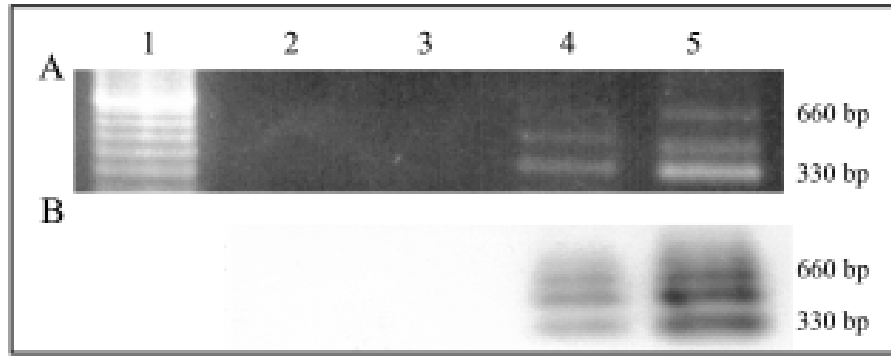

Fig. 2 - A: PCR amplification of sequences of minicircles of kDNA from Trypanosoma cruzi with specific S35/36 primers. Lane 1, 100 bp molecular weight marker; Lane 2, water; Lane 3, P388D1-IL1 DNA (negative control); Lane 4, sucking lice DNA; Lane 5, T. cruzi DNA. B: Southern hybridization with an internal fragment of DNA complementary to the PCR amplification products. Note the $330 \mathrm{bp}$ fragment and its catamer in Lanes 4 and 5 (see methods).

Table 2

Quantitative PCR detection of Trypanosoma cruzi from Pedicinus obtusus captured on baboons' hair, and skin showing positive phenotypic, and genotypic markers for the protozoan infection

\begin{tabular}{|c|c|c|c|c|c|c|}
\hline \multirow[t]{2}{*}{ Animal Id. } & \multirow[t]{2}{*}{ Age } & \multirow[t]{2}{*}{ Sex } & \multicolumn{2}{|c|}{$\mathrm{PCR}^{\S}$} & \multirow{2}{*}{$\begin{array}{c}\text { Lice } \\
\text { (total/bulk) }\end{array}$} & \multirow{2}{*}{$\begin{array}{c}\text { Quantitative PCR } \\
\text { T. cruzi/louse }\end{array}$} \\
\hline & & & kDNA & nDNA & & \\
\hline PCA14660 & $10 \mathrm{mo}$ & $\mathrm{F}$ & + & + & 4 & 20 \\
\hline PCX14499 & $11 \mathrm{mo}$ & M & + & + & 7 & 2.5 \\
\hline PCX14650 & $11 \mathrm{mo}$ & M & + & + & 2 & 40 \\
\hline PCX14011 & $12 \mathrm{mo}$ & $\mathrm{F}$ & + & + & 4 & 10 \\
\hline PCA14190 & $17 \mathrm{mo}$ & $\mathrm{F}$ & + & + & 4 & 13.3 \\
\hline PCA13988 & $17 \mathrm{mo}$ & $\mathrm{F}$ & + & + & 5 & 1 \\
\hline PCX1X3758 & 18 years & M & + & + & 2 & 46 \\
\hline PCA $1 X 2576$ & 20 years & M & + & + & 2 & 42 \\
\hline PCA1X2891 & 20 years & M & + & + & 2 & 41 \\
\hline $13640 *$ & Unknown & - & $\mathrm{Neg}$ & $\mathrm{Neg}$ & 20 & Neg \\
\hline
\end{tabular}

* Twenty lice were captured from hair, and skin from a baboon, which had shown negative phenotypic, and genotypic markers for the T. cruzi infection; ${ }^{\S}$ DNA was extracted from baboon's tissue, and from bulks of lice, and used as template for PCR amplification with primer sets annealing to specific T. cruzi kDNA (SK35/36), and nDNA (PON1/2), as described in methods, and in legend for Figure 4B. 


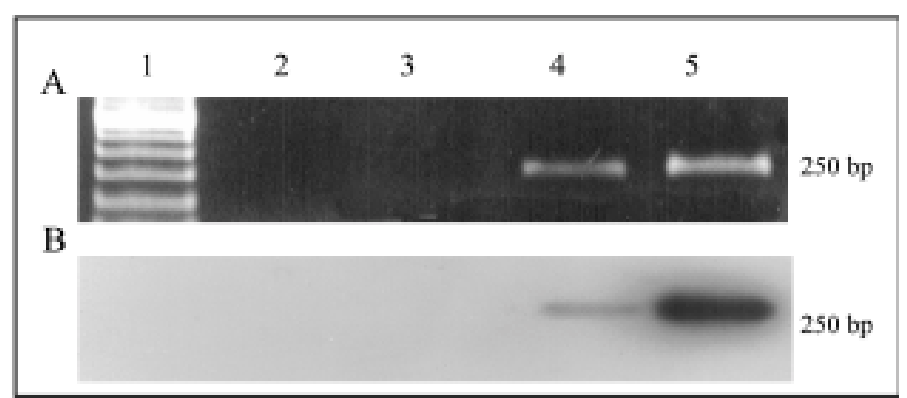

Fig. 3 - A: PCR amplification of sequences of nDNA from Trypanosoma cruzi with specific PON1/2 primers. Lane 1, 100 bp molecular weight marker; Lane 2, water; Lane 3, P388D1IL1 DNA (negative control); Lane 4, sucking lice DNA; Lane 5, T. cruzi DNA. B: Southern hybridization with an internal fragment of DNA complementary to the PCR amplification product. Note the $250 \mathrm{bp}$ bands in lanes 4 and 5 . (See methods).

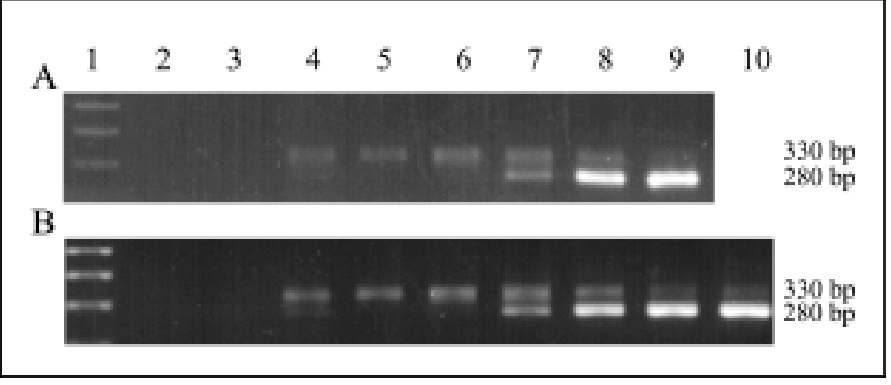

Fig. 4 - A: Quantitation of T. cruzi DNA by competitive PCR. Lane 1, 100 bp molecular weight marker; Lane 2, water; Lane 3, P388D1-IL1 DNA (negative control); Lane 4, T. cruzi DNA equivalent to 1 parasite. Lanes 5-to-8, T. cruzi DNA equivalent to 1 parasite and different quantities of competitor DNA; Lane 5, $0.15 \mathrm{fg}$; Lane 6, $1.5 \mathrm{fg}$; Lane 7, $15 \mathrm{fg}$; Lane 8, $150 \mathrm{fg}$. Note the 330 and $280 \mathrm{bp}$ bands, whose point of equivalence corresponded to $15 \mathrm{fg}$ of competitor DNA that represent circa 1 parasite. B: Quantitation of T. cruzi DNA in sucking lice by competitive PCR. Lane 1, molecular weight marker; Lane 2, water (negative control); Lane 3 P388D1-IL1 DNA; Lane 4, T. cruzi DNA equivalent to 1 parasite. Lanes 5-to-10, 1/50 aliquots of DNA extracted from five sucking lice and various quantities of competitor DNA: Lane 5, 0.15 fg; Lane 6, 0.75 fg; Lane 7, 1.5 fg; Lane 8, 15 fg; Lane 9, $150 \mathrm{fg}$; Lane $101500 \mathrm{fg}$. The point of equivalency between the 330 and the $280 \mathrm{bp}$ bands was at $1.5 \mathrm{fg}$ (Lane 7) of competitor DNA, which is approximately $1 / 10$ of the amount of DNA in 1 parasite. Since each reaction represents $1 / 50$ of the total DNA sample, it was calculated that approximately five parasites were present in five sucking lice.

the result of a standard competitive PCR to detect the DNA equivalent of a single parasite. Then, we determined the quantity of parasite DNA in $100 \mathrm{ng}$ of DNA extracted from bulk samples of lice. Interestingly, the quantity of $23.9 \pm 18.2$ T. cruzi per louse was found. A typical experiment carried out with lice captured from the hair, and from the skin of a 17 month old baboon (Id PCA13988, Table 2) is shown in Figure 4B. The zone of equivalency corresponded to $1.5 \mathrm{fg}$ of competitor DNA. Because this quantity of DNA corresponds to $1 / 10$ parasite $^{5}$, and because the reaction contained $1 / 50$ of the DNA sample, we calculate that there were approximately five $T$. cruzi in this bulk sample of five lice tested.

\section{DISCUSSION}

We have demonstrated for the first time the contamination of bloodsucking lice of the family Pediculidae with $T$. cruzi. However, the only evidence of the protozoan in blood sucking lice was obtained by PCR amplification of T. cruzi kDNA and nDNA sequences in target templates with specific nested set of primers ${ }^{18,23}$. We believe that the sequence of a minicircle kDNA belongs to a living $T$. cruzi, instead of being simply kDNA integrated in the genome of blood cells ${ }^{26}$ sucked in by the louse, because nDNA sequence was also amplified from the lice target template and there is no published evidence that $T$. cruzi nDNA integrates in the genome of a host. These findings suggest, therefore, that sucking lice are capable of transmiting living $T$. cruzi infection among baboons, either by contamination of mucosal surfaces, conjunctiva and skin wounds with its intestinal waste, or by the oral route.

The insects belonging to the family Pediculidae are host specific. They are usually transmitted by direct contact. Of interest, it has been shown that allo grooming by Old World monkeys is an altruistic behavior that removes external parasites from others. In particular, grooming of infants by mothers, which appears to be an important component of maternal care, would contribute to the dissemination of the $T$. cruzi infection, because the mothers pick up lice and eggs of lice and eat them ${ }^{24}$. It has been reported that insectivorous and carnivorous mammals become contaminated with $T$. cruzi through the oral route ${ }^{25}$. The demonstration of $T$. cruzi kDNA and nDNA in lice captured from baboons supports the hypothesis that contamination of nonhuman primates with the protozoan may contribute to the endemicity of Chagas disease in the colony. The estimated number of $T$. cruzi in blood sucking lice $(23.9 \pm 18.2$ parasite per louse) suggests that this protozoan does not multiply in the intestine of the bug. However, dissemination of the infection by lice contaminated with $T$. cruzi is highly plausible, because the infection can be readly acquired through the oral route ${ }^{13,14,17}$. In this regard, it has been shown that reducing the number of the parasites in the inocula may retard but does not prevent the late course of experimental Chagas disease ${ }^{13}$. A single T. cruzi trypomastigote form is sufficient to establish an infection to produce widespread, fatal disease ${ }^{14}$. Although mechanical transmission of $T$. cruzi has been considered by several authors ${ }^{4,8,13-15,17}$, its epidemiological importance remains to be determined.

The sucking lice that occur on human beings comprise the species Pediculus humanus, the body louse and head louse, and Phitirus pubis, the crab louse. These lice occur only on man and not on other hosts. The demonstration of PCR amplification products of $T$. cruzi sequences, with specific $\mathrm{nDNA}^{18}$, and $\mathrm{kDNA}^{23}$ primers, from template DNA obtained from sucking lice of the suborder Anoplura, which infest nonhuman primates, suggests that other sucking lice ( $P$. humanus, and $P$. pubis) also may transmit the infection. However, the hypothetical epidemiological importance of sucking lice in the dissemination of the T. cruzi infections in human beings may be difficult to demonstrate, in the absence of allo grooming and ingestion of external parasites.

The primary vector for transmission of $T$. cruzi in this outdoor, baboon colony in San Antonio, TX, is presumed to be hemiptera, reduviid bugs of the family Triatominae. Several species of triatomids found in Southern United States (Triatoma rubrofasciata, T. sanguesuga) have been related to transmission of Chagas disease ${ }^{22}$. These species have been implicated in an outbreak of acute Chagas disease in a Rhesus monkey colony at Brooks Air Force Base, also in San Antonio ${ }^{10}$. Interestingly, baboon caretakers and researchers carrying on long term scientific work with baboons are aware that these flying insects occasionally are seen at night at the outdoor cages.

We believe that the $T$. cruzi infections in the colony were initiated by reduviid bugs, which possibly continued to transmit them, regardless of the lack of information with respect to the presence of the main vector 


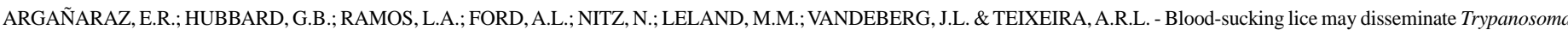
cruzi infection in baboons. Rev. Inst. Med. trop. S. Paulo, 43(5):271-276, 2001.

of Chagas disease in the baboon colony. However, our results suggest that $T$. cruzi infection may be further disseminated in the colony by sucking lice of the suborder Anoplura. We propose that the blood-sucking lice $P$. obtusus infesting Old World monkeys do transmit $T$. cruzi infection, as indicated by the presence of specific kDNA and nDNA sequences, probably acquired during feeding on an infected baboon.

\section{RESUMO}

\section{Piolhos hematófagos podem disseminar infecção pelo Trypanosoma cruzi em babuínos}

As infecções pelo Trypanosoma cruzi e a doença de Chagas são endêmicas em babuínos (Papio hamadryas) reproduzidos em cativeiro na Southwest Foundation for Biomedical Research, em Santo Antonio, Texas. Nós obtivemos produtos de amplificação por PCR do DNA extraído de piolhos colhidos do cabelo e da pele de babuínos chagásicos, com primers aneladores específicos para DNAs nuclear e de cinetoplasto do protozoário. Esses produtos foram hibridizados com suas respectivas seqüências internas complementares. Seqüências selecionadas foram clonadas e o sequenciamento demonstrou a presença de DNA nuclear de $T$. cruzi, e de minicírculo de kDNA. A PCR competitiva com primers de kDNA determinou a quantidade de aproximadamente $23.9 \pm 18.2 \mathrm{~T}$. cruzi por piolho. Este achado sugere que o piolho pode ser um vetor contribuindo para a disseminação de $T$. cruzi na colônia de babuínos.

\section{ACKNOWLEDGMENTS}

We acknowledge Dr. W. C. Van Voorhis, Division of Allergy and Infectious Diseases, SJ-10, Dept. of Medicine, University of Washington, Seattle, USA, for donation of the pT7 Blue vector containing the $280 \mathrm{bp}$ competitor DNA. We thank Ana de Cássia Vexenat, Marie Silva and Sherrian McAnn for technical support. This work was supported in part by NIH grant P51 RR13986 to the Southwest Regional Primate Research Center, and by a grant from the Inter-American Developing Bank/ Financiadora de Estudos e Projetos to the Chagas Disease Multidisciplinary Research Laboratory, Faculty of Medicine of the University of Brasilia, Brazil.

\section{REFERENCES}

1. AVILA, H.A.; SIGMAN, D.S.; COHEN, L.M.; MILLIKAN, R.C. \& SIMPSON, L. Polymerase chain reaction amplification of Trypanosoma cruzi kinetoplast minicircle DNA isolated from whole blood lysates: diagnosis of chronic Chagas disease. Molec. Biochem. Parasit., 48: 211-221, 1991.

2. AZOGUE, E.; LA FUENTE, C. \& DARRAS, C. - Congenital Chagas disease in Bolivia: epidemiological aspects and pathological findings. Trans. roy. Soc. trop. Med. Hyg., 79: 176-180, 1985

3. BITTENCOURT, A.L. - Congenital Chagas disease. Amer. J. Dis. Child., 130: 97-103, 1976

4. BRENER, Z. - Laboratory acquired Chagas disease: an endemic disease among parasitologists? In: MOREL, C.M., ed. Genes and antigens of parasites: a laboratory manual. Rio de Janeiro, Fundação Instituto Oswaldo Cruz, 1984. p. 3-9.

5. CENTURION-LARA, A.; BARRETT, L. \& VAN VOORTHIS, W.C. - Quantitation of parasitemia by competitive polymerase chain reaction amplification of parasite kDNA minicircles during chronic infection with Trypanosoma cruzi. J. infect. Dis., 170: 1334-1339, 1994.
6. CHICHERO, J.A.; BONET, A.H. \& SANTAMARÍA, N. - Estudio de la prevalencia de la enfermedad de Chagas en varones de 20 años de edad en la Provincia de Santiago del Estero. Sem. méd. (B. Aires), 133: 1792-1798, 1967.

7. FARRAR Jr., W.E.; KAGAN, I.G.; EVERTON, F.D. \& SELLERS Jr., T.F. - Serologic evidence of human infection with Trypanosoma cruzi in Georgia. Amer. J. Hyg., 78: 166-170, 1963.

8. GLEISER, C.A.; YAEGER, R.G. \& GHIDONI, J.J. - Trypanosoma cruzi infection in a colony-born baboon. J. Amer. vet. med. Ass., 189: 1225-1226, 1986.

9. HOWARD, J.E. \& RUBIO, M. - Enfermedad de Chagas congénita. I. Estudio clínico y epidemiológico de 30 casos. Bol. chile. Parasit., 23: 107-112, 1968.

10. KASA, T.J.; LATHROP, G.D.; DUPUY, H.J.; BONNEY, C.H. \& TOFT, J.D. - An endemic focus of Trypanosoma cruzi infection in a subhuman primate research colony. J. Amer. vet. med. Ass., 171: 850-854, 1977.

12. LAURIA-PIRES, L. \& TEIXEIRA, A.R.L. - Virulence and pathogenicity associated with diversity of Trypanosoma cruzi stocks and clones derived from Chagas disease patients. Amer. J. trop. Med. Hyg., 55: 304-310, 1996.

13. MARSDEN, P.D. - Trypanosoma cruzi infections in CFI mice. I. Mortality with different doses of trypanosomes. Ann. trop. Med. Parasit., 61: 57-61, 1967a.

14. MARSDEN, P.D. - Trypanosoma cruzi infections in CFI mice. II. Infections induced by different routes. Ann. trop. Med. Parasit., 61: 62-67, 1967b.

15. MILES, M.A. - Trypanosoma cruzi: milk transmission of infection and immunity from mother to young. Parasitology, 65: 1-9, 1972.

16. PAGE, S.L.; CHIU, C. \& GOODMAN, M. - Molecular phylogeny of Old World monkeys (Cercopithecidae) as inferred from gamma-globin DNA sequences. Molec. Phylogenet. Evol., 13: 348-359, 1999.

17. PHILLIPS, N.R. - Experimental studies on the quantitative transmission of Trypanosoma cruzi: considerations regarding the standardization of materials. Ann. trop. Med. Parasit., 54: 60-70, 1960.

18. REQUENA, J.M.; JIMENEZ-RUIZ, A.; SOTO, M.; LOPEZ, M.C. \& ALONSO, C. Characterization of a highly repeated interspersed DNA sequence of Trypanosoma cruzi: its potential use in diagnosis and strain classification. Molec. Biochem. Parasit. 51: 271-280, 1992.

19. ROGERS, J.; MAHANEY, M.C.; WITTE, S.M. et al. - A genetic linkage map of the baboon (Papio hamadryas) genome based on human microsatellite polymorphisms. Genomics, 67: 237-247, 2000 .

20. SCHMUÑIS, G.A. \& SZARFMAN, A. - La enfermedad de Chagas congénita. Medicina (B. Aires), 37: 47-53, 1977.

21. SIMPSON, L. - The mitochondrial genome of kinetoplastid protozoa: genomic organization, transcription, replication, and evolution. Ann. Rev. Microbiol., 41 363-382, 1987.

22. SJOGREN, R.D. \& RYCKMAN, R.E. - Epizootiology of Trypanosoma cruzi in southwestern North America. 8. Nocturnal flights of Triatoma protacta (Uhler) as indicated by collections at black light traps (Hemiptera: Reduvidae: Triatominae). J. med. Ent., 3: 81-92, 1966.

23. STURM, N.R.; DEGRAVE, W.; MOREL, C.M. \& SIMPSON, L. - Sensitive detection and schizodeme classification of Trypanosoma cruzi cells by amplification of kinetoplast minicircle DNA sequences: use in the diagnosis of Chagas disease. Molec. Biochem. Parasit., 33: 205-214, 1989.

24. TANAKA, I. \& TAKEFUSHI, H. - Elimination of external parasites (Lice) is the primary function of grooming in free-ranging Japanese macaques. Anthropol. Sci., 101: 187193, 1993. 
ARGAÑARAZ, E.R.; HUBBARD, G.B.; RAMOS, L.A.; FORD, A.L.; NITZ, N.; LELAND, M.M.; VANDEBERG, J.L. \& TEIXEIRA, A.R.L. - Blood-sucking lice may disseminate Trypanosoma cruzi infection in baboons. Rev. Inst. Med. trop. S. Paulo, 43(5):271-276, 2001.

25. TEIXEIRA, A.R.L. - The Stercorarian Trypanosomes. In: SOULSBY, E.J.L., ed. Immune responses in parasitic infections: Immunology, Immunopathology and Immunoprophylaxis. Boca Raton, CRC Press, 1987. p. 25-115.

26. TEIXEIRA, A.R.L.; ARGAÑARAZ, E.R.; FREITAS Jr., L.H. et al. - Possible integration of Trypanosoma cruzi kDNA minicircles into the host cell genome by infection. Mutat. Res., 305: 197-209, 1994.

27. TEIXEIRA, A.R.L.; FIGUEIREDO, F. \& REZENDE FILHO, J. - Delayed hypersensitivity to Trypanosoma cruzi antigens. II. Use of the skin test with the T12E antigen for the diagnosis of Chagas disease. Rev. Soc. bras. Med. trop., 28: 259-265, 1995.

28. TINOCO, D.L.; GARCIA, M.P.; LAURIA-PIRES, L.; SANTANA, J.M. \& TEIXEIRA, A.R. - The use of four immunological exams for the determination of Chagas disease prevalence in streetsweepers of the City Sanitation Service in the Federal District. Rev. Soc. bras. Med. trop., 29: 33-40, 1996.
29. TOFT, J.D. \& EBERHARD, M.L. - Parasitic diseases. In: BENNET, B.T.; ABEE, C.R $\&$ HENRICKSON, R., ed. Nonhuman primates in biomedical research. New York, Academic Press, 1998. p. 115-116.

30. VANDEBERG, J.L. \& WILLIAMS-BLANGERO, S. - Strategies for using nonhuman primates in genetic research on multifactorial diseases. Lab. Anim. Sci., 46: 146$151,1996$.

31. WORLD HEALTH ORGANIZATION - Control of Chagas disease. Report of a WHO Expert Committee. Wld. Hlth. Org. techn. Rep. Ser., (811): 1-95, 1991.

Received: 09 March 2001

Accepted: 30 May 2001 